\title{
Cerium-144 Beta Radiation
}

National Cancer Institute

\section{Source}

National Cancer Institute. Cerium-144 Beta Radiation. NCI Thesaurus. Code C129639.

Beta radiation produced by the decay of cerium- 144 . 